\title{
Habitat and Landscape Suitability as Indicators of Bird Abundance in Created and Restored Wetlands
}

\author{
Jordan W. Mora, ${ }^{1}$ John N. Mager III, ${ }^{2}$ and Douglas J. Spieles ${ }^{3}$ \\ ${ }^{1}$ Waquoit Bay National Estuarine Research Reserve, East Falmouth, MA 02536, USA \\ ${ }^{2}$ Department of Biological \& Allied Health Sciences, Ohio Northern University, Ada, OH 45810, USA \\ ${ }^{3}$ McPhail Center for Environmental Studies, Denison University, Granville, OH 43023, USA \\ Correspondence should be addressed to Douglas J. Spieles, spielesd@denison.edu
}

Received 6 June 2011; Accepted 14 July 2011

Academic Editor: A. Ridley

Copyright ( $\odot 2011$ Jordan W. Mora et al. This is an open access article distributed under the Creative Commons Attribution License, which permits unrestricted use, distribution, and reproduction in any medium, provided the original work is properly cited.

\begin{abstract}
We used aerial photography, field measurements, and bird surveys to evaluate 7 Ohio mitigation wetlands for their capacity to support avian guilds at both local and landscape scales. At the local scale, we assessed each wetland with habitat suitability indices (HSI) for eight wetland-dependent bird species as indicators for four guilds: wading, diving, dabbling, and emergent dependent. We characterized landscapes within $2.5 \mathrm{~km}$ of each wetland by measuring the buffer width, road density, connectedness, and anthropogenic land development. The changes in landscape variables over time were determined by comparison of aerial photos taken near the time of wetland construction and near the time of this study. Bird abundance data were poorly correlated with HSI scores but were well described with logistic models of buffer width, wetland area, and road density. Our results suggest that landscape variables are better predictors of bird abundance than HSI scores for these guilds in these wetlands.
\end{abstract}

\section{Introduction}

Habitat for wetland-dependent species in the United States has declined in quality and quantity over a long history of wetland drainage, filling, and impairment $[1,2]$. Recently, national policies of mandatory mitigation have slowed the rate of wetland loss [2], and for the period of 1998-2004 Dahl [3] estimated a net gain in total wetland area for the first time. Through wetland creation and restoration the United States has thus achieved and exceeded the goal of no-netloss, but there continue to be questions about the ecological effectiveness of mitigation wetlands [4]. In particular, the capacity of created and restored wetlands to support diverse biota is inconsistent. Many variables can influence the establishment of a diverse community or certain desirable species, and it is now clear that biotic restoration is dependent not only on characteristics of the constructed ecosystem but also on its placement within the landscape $[5,6]$. The relative importance of local and landscape factors remains a central question in restoration ecology.

Created and restored wetlands are typically designed for the establishment of appropriate biotic communities and abiotic conditions within the zone of inundation. These local attributes are planned according to prescribed performance criteria (e.g., diversity of the native plant community, basin depth, or hydrologic regime) and for the ecosystem services they provide (e.g., flood retention capacity, habitat provision). For example, local attributes are important in the restoration or creation of wetland-dependent bird habitat. Fairbairn and Dinsmore [7] found coverage of emergent vegetation, total wetland area, and perimeter-to-area ratio to be predictive of bird community diversity in prairie pothole wetlands. Other studies [8-10] have shown correlation of local wetland characteristics with the occurrence of particular bird species, which are used as indicators of habitat quality. Habitat suitability models have been used in speciesbased ecosystem evaluation and management at the local scale $[11,12]$.

Of course, local attributes occur within a landscape matrix, and the landscape is a critical factor in wetland restoration or creation for avian habitat. Numerous studies provide evidence that landscape attributes like road density [13], proximity to other ecosystems $[7,14]$, and anthropogenic development [15] affect local bird diversity. In general 


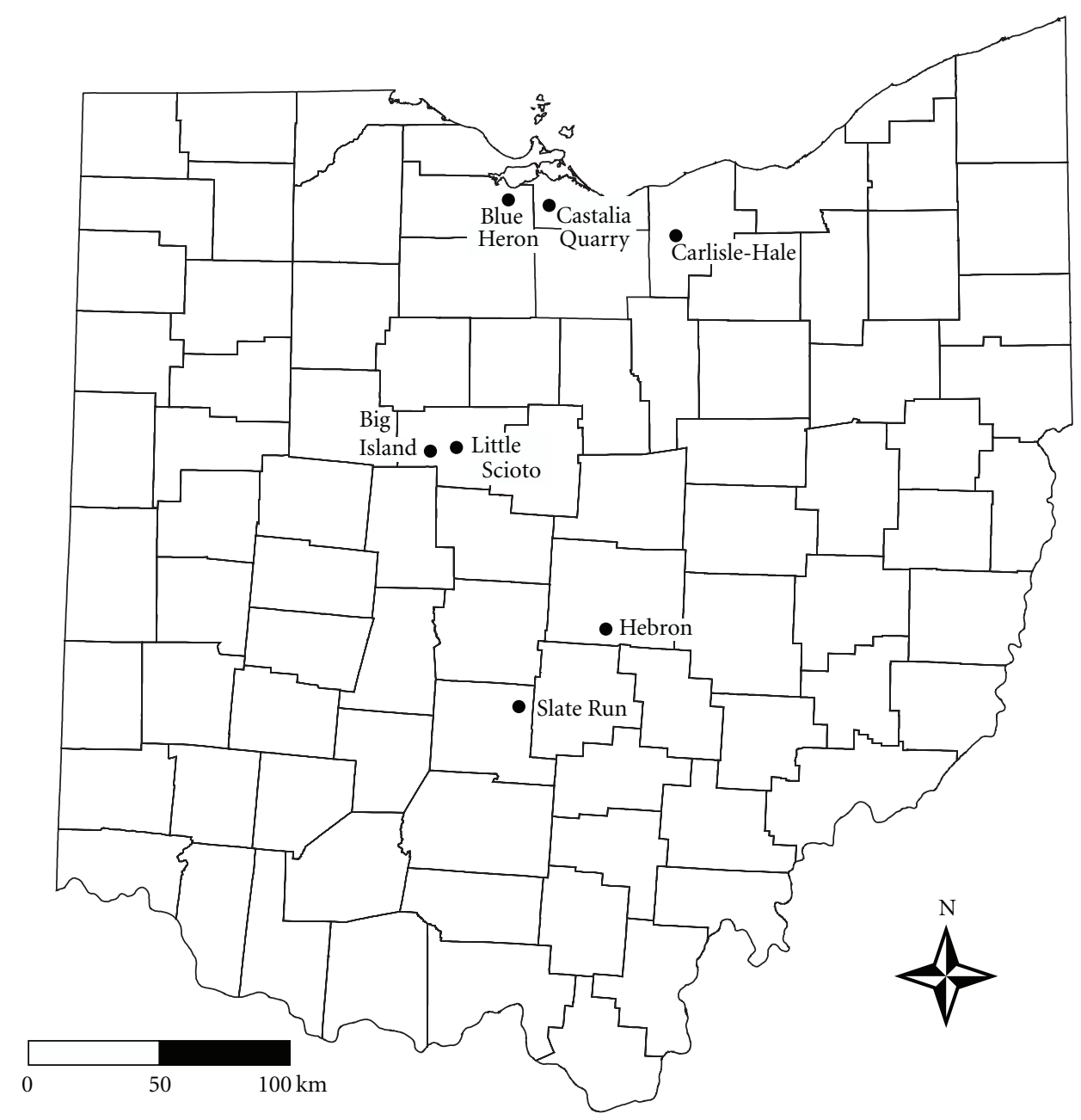

Figure 1: Location of Ohio mitigation bank wetlands considered in this study.

wetland bird diversity has been shown to decrease in response to increased road density, habitat fragmentation and isolation, and anthropogenic land use in the landscape [13, $16,17]$. And, as with local attributes, landscape factors have been associated with the presence of particular bird species $[18,19]$.

The establishment of a suitable habitat for indicator bird species or for general avian diversity are noble goals of wetland creation and restoration. However, analysis of habitat suitability for bird guilds may provide a better assessment of the wetland's capacity to support a functional community [20, 21]. Guilds offer certain advantages over the use of single species or general diversity in ecosystem assessment, including the ability to analyze the viability of functional niches [21]. A variety of bird guilds have been used in the analysis of wetland habitat quality including those based on specialist-to-generalist gradient [22], response to landscape disturbance [23], migratory status [24], habitat preference [25], and feeding preference [26]. Verner [27] proposed the use of bird guilds defined according to zones of habitat as an indicator of an ecosystem's capacity to support wildlife. This approach may be particularly useful in the evaluation of mitigation wetlands, as it would allow for a direct assessment of the efficacy of wetland design.

In this study, we use physical aspects of restored and created wetlands as predictors of structural suitability for eight bird species in four habitat-zone guilds: wading, diving, dabbling, and emergent dependent. We assess the extent to which the construction of suitable local habitat characteristics corresponds with the actual abundance of birds from the respective guilds. We also analyze the relative effectiveness of structural wetland attributes and landscape factors in the prediction of avian guild presence in restored and constructed wetlands.

\section{Methods}

We studied local attributes, landscape attributes, and bird abundance in seven active mitigation bank wetlands in Ohio, USA (Figure 1). In 2006 these wetlands ranged from one to thirteen years since construction $(7.8 \pm 1.5$ years, mean $\pm \mathrm{SE})$, with the oldest constructed in 1993 and the youngest in 2005. The wetland mitigation bank objectives and site plans were obtained from the Army Corps Districts of Huntington 
TABLE 1: Ohio wetland mitigation bank information, provider and dates for Early and Recent aerial photographs. All Early aerial photographs were United States Geological Survey Digital Ortho-Quadrangles.

\begin{tabular}{|c|c|c|c|c|c|c|c|c|}
\hline Wetland site & $\begin{array}{l}\text { Army corps } \\
\text { district }\end{array}$ & $\begin{array}{c}\text { Area } \\
\text { (ha) }\end{array}$ & $\begin{array}{c}\text { Year } \\
\text { created }\end{array}$ & $\begin{array}{l}\text { Early } \\
\text { photo }\end{array}$ & $\begin{array}{l}\text { Resolution } \\
\quad(\mathrm{m})\end{array}$ & $\begin{array}{l}\text { Recent } \\
\text { photos }\end{array}$ & $\begin{array}{l}\text { Resolution } \\
\quad(\mathrm{m})\end{array}$ & Provider \\
\hline Big Island & Huntington & 137 & 1994 & $4 / 7 / 94$ & 5.0 & $\begin{array}{c}1 / 1 / 04 \\
7 / 16 / 06\end{array}$ & $\begin{array}{l}5.0 \\
1.0\end{array}$ & $\begin{array}{l}\text { GlobeXplorer } \\
\text { MetroFlyer }\end{array}$ \\
\hline Blue Heron & Buffalo & 59 & 2005 & $3 / 18 / 95$ & 5.0 & $\begin{array}{c}1 / 1 / 04 \\
7 / 25 / 06\end{array}$ & $\begin{array}{l}6.0 \\
1.0\end{array}$ & $\begin{array}{l}\text { GlobeXplorer } \\
\text { MetroFlyer }\end{array}$ \\
\hline Carlisle-Hale & Buffalo & 36 & 1998 & $4 / 20 / 94$ & 5.0 & $\begin{array}{l}9 / 1 / 05 \\
9 / 1 / 05\end{array}$ & $\begin{array}{l}6.0 \\
1.0\end{array}$ & $\begin{array}{l}\text { AirPhoto USA } \\
\text { AirPhoto USA }\end{array}$ \\
\hline Castalia Quarry & Buffalo & 16 & 1998 & $3 / 31 / 97$ & 5.0 & $\begin{array}{l}9 / 1 / 05 \\
9 / 1 / 05\end{array}$ & $\begin{array}{l}5.0 \\
0.8\end{array}$ & $\begin{array}{l}\text { AirPhoto USA } \\
\text { AirPhoto USA }\end{array}$ \\
\hline Hebron & Huntington & 15 & 1993 & $4 / 23 / 94$ & 5.0 & $\begin{array}{l}10 / 1 / 04 \\
10 / 1 / 04\end{array}$ & $\begin{array}{l}5.0 \\
0.8\end{array}$ & $\begin{array}{l}\text { AirPhoto USA } \\
\text { AirPhoto USA }\end{array}$ \\
\hline Little Scioto & Huntington & 195 & 2000 & 4/7/94 & 5.0 & $\begin{array}{c}1 / 1 / 04 \\
7 / 16 / 06\end{array}$ & $\begin{array}{l}7.0 \\
1.0\end{array}$ & $\begin{array}{l}\text { GlobeXplorer } \\
\text { MetroFlyer }\end{array}$ \\
\hline Slate Run & Huntington & 78 & 1999 & $3 / 23 / 94$ & 5.0 & $\begin{array}{l}10 / 1 / 04 \\
10 / 1 / 04 \\
\end{array}$ & $\begin{array}{l}6.0 \\
1.5 \\
\end{array}$ & $\begin{array}{l}\text { AirPhoto USA } \\
\text { AirPhoto USA }\end{array}$ \\
\hline
\end{tabular}

and Buffalo. To facilitate spatial analyses, we obtained aerial photographs of each wetland and its surrounding landscape. Each wetland was visited once between early June and late September of 2006 for verification of aerial photograph analyses and for measurement of local attributes. Wetlands were visited on two additional occasions in 2006 and 2007 for avian survey.

Analysis of habitat at the local scale included a bird habitat field survey. Eight waterbird species were chosen as proxies to represent four guilds: two wading species, the great blue heron (Ardea herodias), and great egret (Ardea alba); two diving species, the lesser scaup (Aythya affinis) and American coot (Fulica americana); two dabbling ducks, the blue-winged teal (Anas discors) and wood duck (Aix sponsa); and two emergent-dependent bird species, the marsh wren (Cistothorus palustris) and red-winged blackbird (Agelaius phoeniceus). These species were selected according to their primary feeding and nesting guild, their geographic range, and the availability of a US Fish and Wildlife Service Habitat Suitability Index (HSI) model for each (corresponding references given Table 6). The HSI scores are based on a zero-to-one scale in which a score of one indicates ideal habitat and zero indicates an absence of suitable habitat. In order to complete the Habitat Suitability Indices for each guild, several field measurements were required including the cover, growth form, and height of dominant vegetation, average water depth, degree of vegetation interspersion, average water depth under emergent herbaceous and woody vegetation, emergent plant identification, as well as buffer width and the capacity for foraging and nesting in the regional proximity of the wetland (Table 6). HSI scores were averaged for each guild as an estimate of guild suitability in each wetland.

A United States Geological Survey (USGS) Digital Orthophoto Quadrangle (DOQ) from a time prior to or shortly after the construction of each mitigation bank (1988-2001) was obtained for each site through the online database
TerraServer. We digitized these "early" landscape photographs to a radius $2.5 \mathrm{~km}$ from the center of each wetland complex using Global Mapper v. 7 (Global Mapper Software, LLC). Land uses were organized into four categories: agriculture, residential/urban, natural area (wooded, grassland, wetland), and open water. "Recent" (January 2004 to July 2006) aerial photographs were obtained for each site through TerraServer or from MetroFlyer Aerial and Architectural Photography (Table 1) and georectified with Global Mapper v.7. For each wetland, we digitized the surrounding landscape within a radius of $2.5 \mathrm{~km}$ on a recent photograph using the same categories as the DOQ. A second recent photograph of higher resolution was used to digitize basin and buffer features. The early and recent aerial photographs used for landscape analyses differed in age by $9.9 \pm 0.3$ y (mean \pm $\mathrm{SE})$. As adjusted for wetland area, these photographs were compared to determine the rate of residential development and road density in the landscape surrounding the wetland, and the connectedness of the wetland with other natural areas.

From the aerial photograph analyses we computed five landscape variables: average buffer width, connectedness, road density, rate of residential development, and landscape development index. Buffer width was defined as the average distance from the edge of the wetland to the nearest anthropogenic land use (e.g., farm, road, or residential area) in each of the four cardinal directions. Following Findlay and Houlahan [17] we determined road density by dividing the total length of road within the $2.5 \mathrm{~km}$ radius by the area within the radius, including the wetland itself. We did not differentiate roads by type or traffic load. We measured connectedness as the ratio of area in a conterminous polygon of natural area (e.g., forest, wetland, grassland, and open water) around and including the wetland to total area in a $2.5 \mathrm{~km}$ radius from the center of the wetland after Whited et al. [13]. Using the early and recent aerial photographs the change in connectedness and road density per year 
TABle 2: Habitat Suitability Index values for Ohio mitigation bank wetlands in 2006. Values have a possible range of zero to one, with one representing ideal habitat. E-D = Emergent-dependent birds; LS = lesser scaup; AC = American coot; GE = great egret; GBH = great blue heron; $\mathrm{BWT}=$ blue-winged teal; $\mathrm{WD}=$ wood duck; $\mathrm{MW}=$ marsh wren; RWB = red-winged blackbird.

\begin{tabular}{|c|c|c|c|c|c|c|c|c|c|}
\hline & \multicolumn{2}{|c|}{ Diving } & \multicolumn{2}{|c|}{ Wading } & \multicolumn{2}{|c|}{ Dabbling } & \multicolumn{2}{|c|}{ E-D birds } & \multirow{2}{*}{ Mean \pm SE } \\
\hline & LS & $\mathrm{AC}$ & GE & $\mathrm{GBH}$ & BWT & WD & MW & RWB & \\
\hline Big Island & 0.49 & 0.30 & 0.10 & 1.0 & 0.32 & 0.41 & 0.30 & 0.70 & $0.45 \pm 0.09$ \\
\hline Blue Heron & 0.58 & 0.62 & 0.10 & 1.0 & 0.20 & 0.20 & 0.26 & 0.64 & $0.45 \pm 0.11$ \\
\hline Carlisle-Hale & 0.23 & 0.59 & 0.00 & 0.95 & 0.10 & 0.20 & 0.08 & 0.30 & $0.31 \pm 0.11$ \\
\hline Castalia Quarry & 0.05 & 0.38 & 0.10 & 0.00 & 0.17 & 0.10 & 0.02 & 0.01 & $0.10 \pm 0.04$ \\
\hline Hebron & 0.36 & 0.67 & 0.00 & 0.00 & 0.26 & 0.21 & 0.20 & 0.00 & $0.21 \pm 0.08$ \\
\hline Little Scioto & 0.50 & 0.85 & 0.31 & 1.00 & 0.45 & 0.30 & 0.36 & 0.90 & $0.58 \pm 0.10$ \\
\hline Slate Run & 0.29 & 0.28 & 0.00 & 0.97 & 0.12 & 0.20 & 0.24 & 0.01 & $0.27 \pm 0.11$ \\
\hline Mean & 0.36 & 0.48 & 0.18 & 0.70 & 0.19 & 0.24 & 0.21 & 0.39 & \\
\hline Standard Error & 0.08 & 0.08 & 0.09 & 0.18 & 0.06 & 0.04 & 0.05 & 0.13 & \\
\hline
\end{tabular}

were determined by dividing the early to recent difference by the number of years elapsed. We used the Landscape Development index (LDI) of Brown and Vivas [37] as adapted to Ohio by Mack [28] to evaluate the landscape in a $1 \mathrm{~km}$ radius from each wetland. The LDI is a weighted average of coefficients that rank various land use classes from one (natural system) to ten (highly modified urban environment) to quantify the anthropogenic stress in the wetland landscape.

Each wetland was surveyed for birds on two occasions, once in summer 2006 and once in summer 2007. Birds were surveyed with the round count method [38], in which the wetland is circumnavigated by the surveyor. Each survey took place on a single day, beginning one half hour before sunrise and continuing until circumnavigation was complete; survey effort was thus related to wetland area. We categorized bird abundance according to habitat preferences for nesting and foraging according to Ehrlich et al. [39]. Wetland-dependent birds were classified by dependence on mud flats and shallow emergent zones (wading birds), deep open water (diving birds), shallow open water (dabbling birds), and emergent vegetation (emergent-dependent birds). Bird species without a clear wetland association were not considered in this study.

We tested mean HSI statistics for similarity among the eight waterbird species with one-way analysis of variance (ANOVA; SPSS 15.0). Significant differences among mean HSI scores were determined with Tukey's pairwise comparisons. The significance of difference between the mean area of natural, agricultural, open water, and residential/urban land in early and recent landscape surrounding each wetland was determined with paired $t$-tests. We also compared the early and recent buffer width, connectedness, road density, and LDI with paired $t$-tests. Pearson's $r$ was used to describe correlations among bird survey data, HSI variables, landscape variables, and wetland age. We used curve fitting analyses to determine appropriate data transformation for linear regression. Significant predictors were transformed according to the logistic equation $\left(K^{-1}+\beta_{0} \beta_{1}{ }^{x}\right)^{-1}$, where $K$ is the curve's upper boundary value, $\beta_{0}$ and $\beta_{1}$ are regression coefficients, and $x$ is the predictor value. Significance for all tests was evaluated at $\alpha=0.05$; marginal significance is noted for correlation and regression models at $\alpha<0.10$.

\section{Results}

The wetlands considered in this study encompass 536 ha, with a mean $( \pm$ SE) area of $76.6 \pm 25.4$ ha. Upland buffer between the wetland and the nearest anthropogenic land use averaged $255 \pm 92 \mathrm{~m}$. Based on our analyses of early aerial photographs, the wetlands were constructed in landscapes ( $2.5 \mathrm{~km}$ radius) that are primarily agriculture $(60 \pm 4 \%)$ and natural ( $24 \pm 3 \%$; predominantly wooded) land use, with $6 \pm 1 \%$ of the surrounding landscape in open water and $8 \pm 2 \%$ in residential or urban development. The land area surrounding the mitigation bank wetlands in natural use $(P=0.46)$, agriculture $(P=0.44)$, and open water $(P=$ 0.27 ) were statistically unchanged from early to recent photograph while land area in residential or urban development increased by an average of $21 \pm 8$ ha, from $7.5 \pm 2 \%$ in the early photograph to $8.6 \pm 2 \%$ in the recent photograph $(P=0.07)$.

Mean Habitat Suitability Index values differ significantly among waterbird species $\left(F_{7,55}=4.3 ; P<0.001\right)$ and among wetlands $\left(F_{6,55}=2.9 ; P=0.02\right.$; Table 2$)$. Across all wetlands, habitat suitability was higher for wading $(0.40 \pm 0.12)$ and diving $(0.44 \pm 0.06)$ guilds than for dabbling $(0.23 \pm 0.03)$ and emergent dependent $(0.29 \pm 0.08)$, though the difference was not statistically significant $\left(F_{3,55}=1.5 ; P=0.23\right)$. Connectedness to natural areas in the landscapes surrounding the wetlands in this study ranged from moderate connectedness to relative isolation (Table 3 ). The average connectedness at the time of this study was $12.5 \pm 3.9 \%$, an increase from the early photographs $(11.4 \pm 3.8 \% ; P=0.03)$. Road density at the time of this study $(11 \pm 0.8 \mathrm{~m} / \mathrm{ha})$ had not changed significantly since wetland construction $(P=0.3)$. The slight increase in residential development from early to recent photographs corresponds with an average annual increase of 
TABle 3: Characteristics of the landscape surrounding Ohio mitigation bank wetlands. Connectedness, road density, and residential development are determined to a radius $2.5 \mathrm{~km}$ from the center of each wetland while the LDI [28] is calculated for a $1 \mathrm{~km}$ radius.

\begin{tabular}{|c|c|c|c|c|c|c|c|}
\hline \multirow[t]{2}{*}{ Wetland } & \multirow[t]{2}{*}{$\begin{array}{l}\text { Average upland } \\
\text { buffer }(\mathrm{m})\end{array}$} & \multicolumn{2}{|c|}{$\begin{array}{l}\text { Connectedness } \\
\text { (percentage of area } \\
\text { to } 2.5 \mathrm{~km} \text { ) }\end{array}$} & \multicolumn{2}{|c|}{$\begin{array}{l}\text { Road density } \\
(\mathrm{m} / \text { ha to } 2.5 \mathrm{~km})\end{array}$} & \multirow[t]{2}{*}{$\begin{array}{c}\text { Rate of residential } \\
\text { development } \\
\text { (ha/yr to } 2.5 \mathrm{~km})\end{array}$} & \multirow[t]{2}{*}{$\begin{array}{c}\text { Land use } \\
\text { development } \\
\text { (LDI to } 1 \mathrm{~km} \text { ) }\end{array}$} \\
\hline & & Early & Recent & Early & Recent & & \\
\hline Big Island & 619 & 24.5 & 25.5 & 10 & 11 & 1.3 & 2.0 \\
\hline Blue Heron & 89 & 0.0 & 0.0 & 11 & 11 & 1.0 & 3.8 \\
\hline Carlisle-Hale & 104 & 8.4 & 12.0 & 16 & 15 & 8.3 & 3.8 \\
\hline $\begin{array}{l}\text { Castalia } \\
\text { Quarry }\end{array}$ & 20 & 25.0 & 26.5 & 11 & 11 & 2.1 & 3.2 \\
\hline Hebron & 205 & 4.0 & 3.9 & 13 & 12 & 0.0 & 3.7 \\
\hline Little Scioto & 165 & 4.9 & 5.4 & 8 & 8 & 1.2 & 1.9 \\
\hline Slate Run & 586 & 13.2 & 14.3 & 13 & 13 & 0.0 & 3.5 \\
\hline Average & 255 & 11.4 & 12.5 & 12 & 12 & 2.0 & 3.1 \\
\hline $\begin{array}{l}\text { Standard } \\
\text { Error }\end{array}$ & 92 & 3.8 & 3.9 & 1.0 & 0.8 & 1.1 & 0.3 \\
\hline
\end{tabular}

TABLE 4: Pearson's correlation ( $r$ ) of diving, dabbling, wading, and emergent-dependent bird abundance with habitat and landscape variables of seven Ohio mitigation bank wetlands. Habitat and landscape variables include a composite Habitat Suitability Index (HSI) value for each guild, wetland area, mean width of upland buffer surrounding each wetland (buffer), connectedness of natural habitat within $2.5 \mathrm{~km}$ of each wetland (connect), road density within $1 \mathrm{~km}$ of each wetland (Road), Landscape Development Index (LDI), and wetland age. Significance indicated at ${ }^{*} \alpha=0.10$ and ${ }^{* *} \alpha=0.05$.

\begin{tabular}{lccccccc}
\hline & HSI & Area & Buffer & Connect & Road & LDI & Age \\
\hline Diving & -0.27 & 0.19 & $0.86^{* *}$ & -0.17 & -0.21 & 0.02 & 0.32 \\
Dabbling & 0.44 & $0.67^{* *}$ & $0.70^{* *}$ & -0.11 & $-0.56^{*}$ & -0.36 & 0.11 \\
Wading & 0.41 & $0.72^{* *}$ & $0.59^{*}$ & 0.45 & $-0.70^{* *}$ & $-0.62^{*}$ & 0.40 \\
Emergent & -0.10 & -0.06 & $0.69^{* *}$ & -0.36 & 0.44 & 0.44 & 0.32 \\
\hline
\end{tabular}

$2.0 \pm 1.1 \mathrm{ha} / \mathrm{yr}$ in residential or urban area in the landscape within a $2.5 \mathrm{~km}$ radius of these wetlands. The Land Use Development Index (determined for a $1 \mathrm{~km}$ radius from each wetland) ranged from 1.9 to 3.8 for these landscapes, with a mean of $3.1 \pm 0.3$.

Thirty-five wetland-dependent bird species were represented by 1437 individuals in the seven wetlands surveyed (Table 7). Emergent-dependent birds were the most abundant (618), followed by dabbling (589), diving (157), and wading birds (73). Bird abundance by wetland ranged widely, from 444 at Slate Run to 17 at Castalia Quarry. Abundances of the eight representative species in this study were poorly correlated with the corresponding HSI at these seven wetlands. With the exception of blue-winged teal $(r=$ 0.7 ), no species HSI correlation value exceeded 0.35 and no guild suitability score exceeded 0.44 . Landscape variables were more strongly correlated with bird abundances than HSI values (Table 4). For all four guilds, buffer width was positively correlated with abundance (Table 4). For dabbling and wading birds, total wetland area was positively correlated with abundance while road density and LDI were negatively correlated (Table 4 ). Wetland age was not significantly correlated with the abundance of birds in any category. The relationships of predictor variables with guild abundance were nonlinear and best described with logistic models. Regression model parameters for significant predictors are given in Table 5. Buffer width, wetland area, and road density were the only significant predictors of bird abundance for any guild.

\section{Discussion}

In this study we attempt to discern attributes of mitigation wetlands that are useful predictors of bird abundance. At the local scale, characteristics of created and restored wetlands such as water depth, hydrologic regime, substrate, and vegetation form, cover, and interspersion are ostensibly all design criteria. These characteristics are also components of the Habitat Suitability Indices for bird species in this study (Table 6). We test the use of HSI scores as predictors of bird abundance and find them to be ineffective. Though all eight species occurred in at least one wetland in the study, only the abundance of the blue-winged teal was predicted reasonably well by HSI scores $(r=0.7, P=0.04)$. The blue-winged teal HSI, more than any other HSI used in this study, is strongly predicated on landscape attributes such as regional wetland density, proximity, and area. The generally poor correlation of the other HSI scores with bird abundance suggests that the design of created and restored 
TABLE 5: Linear regression models of bird abundance based on local and landscape variables transformed by the logistic equation: Guild abundance $=\left(K^{-1}+\beta_{0} \beta_{1}{ }^{x}\right)^{-1}$. A single predictor is used in each model.

\begin{tabular}{lccccccc}
\hline Guild & Predictor & $K$ & $\beta_{0}$ & $\beta_{1}$ & $r^{2}$ & $F$ \\
\hline Diving & Buffer width & 100 & 2.740 & 0.990 & 0.64 & 9.005 & 0.03 \\
Dabbling & Buffer width & 250 & 0.054 & 0.994 & 0.53 & 5.626 \\
& Wetland area & 250 & 0.056 & 0.983 & 0.44 & 3.952 \\
Wading & Wetland area & 1000 & 0.441 & 0.987 & 0.62 & 8.145 \\
& Road density & 1000 & 0.006 & 1.324 & 0.52 & 5.427 \\
Emergent & Buffer width & 300 & 0.033 & 0.996 & 0.47 & 4.507 & 0.04 \\
\hline
\end{tabular}

TABLE 6: Waterbird species habitat characteristics based on Habitat Suitability Models as referenced.

\begin{tabular}{|c|c|c|c|c|}
\hline Guild & species & $\begin{array}{l}\text { Hydrologic regime } \\
\text { preference }\end{array}$ & HSI criteria & Source \\
\hline \multirow{7}{*}{ Diving } & American coot & Semipermanent & Percent emergent herbaceous vegetation & [29] \\
\hline & & & Herbaceous vegetation-open water edge & \\
\hline & & & Hydrologic regime & \\
\hline & Lesser scaup & Permanent & Percent herbaceous cover & {$[30]$} \\
\hline & & & Average height of herbaceous vegetation & \\
\hline & & & Percent shrub crown cover & \\
\hline & & & Hydrologic regime & \\
\hline \multirow{6}{*}{ Dabbling } & Wood duck & Permanent & Density of potential nest sites & {$[31]$} \\
\hline & & & Percent cover woody and herbaceous vegetation & \\
\hline & & & Interspersion & \\
\hline & Blue-winged teal & Semi-permanent & Wetland density to $0.9 \mathrm{~km}$ radius & {$[32]$} \\
\hline & & & Average height of herbaceous vegetation & \\
\hline & & & Distance to nesting habitat & \\
\hline \multirow{8}{*}{ Wading } & Great egret & $\begin{array}{l}\text { Semipermanent to } \\
\text { permanent }\end{array}$ & Appropriate water depth & {$[33]$} \\
\hline & & & Submerged and emergent cover at optimal depth & \\
\hline & & & Appropriate water depth under woody cover & \\
\hline & & & Height of woody vegetation & \\
\hline & & & Distance from nest site to road or disturbed area & \\
\hline & Great blue heron & Permanent & Distance to potential rookery & {$[34]$} \\
\hline & & & Presence of suitable prey and foraging substrate & \\
\hline & & & Width of buffer for foraging and nesting sites & \\
\hline \multirow{9}{*}{$\begin{array}{l}\text { Emergent- } \\
\text { dependent }\end{array}$} & Marsh wren & Seasonally & Growth form of emergent vegetation & {$[35]$} \\
\hline & & & Percent herbaceous and woody vegetation cover & \\
\hline & & & Mean water depth & \\
\hline & Red-winged & $\begin{array}{l}\text { Semipermanent to } \\
\text { permanent }\end{array}$ & Growth form of emergent vegetation & {$[36]$} \\
\hline & blackbird & & Percent herbaceous vegetation cover & \\
\hline & & & Presence of carp & \\
\hline & & & Presence of Odonate nymphs & \\
\hline & & & Hydrologic regime & \\
\hline & & & Presence of regional foraging sites & \\
\hline
\end{tabular}


TABLE 7: Bird survey totals by wetland.

\begin{tabular}{|c|c|c|c|c|c|c|c|c|c|}
\hline Species & Guild & Big Island & Blue Heron & Slate Run & Hebron & Little Scioto & Castalia Quarry & Carlisle-Hale & Total \\
\hline American widgeon & Dabbler & 0 & 0 & 0 & 0 & 15 & 0 & 0 & 15 \\
\hline Blue-winged teal & Dabbler & 32 & 15 & 38 & 30 & 50 & 0 & 0 & 165 \\
\hline Mallard & Dabbler & 21 & 5 & 61 & 2 & 30 & 4 & 0 & 123 \\
\hline Muscovy duck & Dabbler & 0 & 0 & 0 & 3 & 0 & 0 & 0 & 3 \\
\hline Northern shoveler & Dabbler & 0 & 2 & 0 & 4 & 4 & 0 & 0 & 10 \\
\hline Wood duck & Dabbler & 3 & 0 & 32 & 8 & 0 & 0 & 1 & 44 \\
\hline Canada goose & Dabbler & 51 & 4 & 59 & 30 & 64 & 1 & 11 & 220 \\
\hline Mute swan & Dabbler & 0 & 0 & 6 & 0 & 0 & 0 & 0 & 6 \\
\hline Trumpeter swan & Dabbler & 1 & 0 & 0 & 0 & 0 & 0 & 0 & 1 \\
\hline Tundra swan & Dabbler & 0 & 0 & 0 & 0 & 2 & 0 & 0 & 2 \\
\hline American coot & Diver & 29 & 0 & 60 & 17 & 9 & 0 & 0 & 115 \\
\hline Belted kingfisher & Diver & 0 & 0 & 5 & 1 & 0 & 0 & 0 & 6 \\
\hline Caspian tern & Diver & 0 & 0 & 1 & 0 & 0 & 0 & 0 & 1 \\
\hline Common goldeneye & Diver & 0 & 0 & 0 & 2 & 0 & 0 & 0 & 2 \\
\hline Common merganser & Diver & 0 & 1 & 0 & 0 & 0 & 0 & 0 & 1 \\
\hline Lesser scaup & Diver & 0 & 0 & 3 & 2 & 0 & 0 & 0 & 5 \\
\hline Pied-billed grebe & Diver & 7 & 0 & 1 & 2 & 0 & 0 & 0 & 10 \\
\hline Redhead & Diver & 0 & 0 & 1 & 2 & 0 & 0 & 0 & 3 \\
\hline Ring-necked duck & Diver & 0 & 0 & 3 & 5 & 6 & 0 & 0 & 14 \\
\hline American tree swallow & Emergent & 17 & 12 & 38 & 5 & 4 & 0 & 2 & 78 \\
\hline Cedar waxwing & Emergent & 0 & 0 & 2 & 12 & 0 & 0 & 0 & 14 \\
\hline Marsh wren & Emergent & 4 & 0 & 0 & 0 & 0 & 0 & 0 & 4 \\
\hline Red-winged blackbird & Emergent & 77 & 59 & 84 & 90 & 20 & 3 & 11 & 344 \\
\hline Common yellowthroat & Emergent & 2 & 8 & 11 & 8 & 0 & 2 & 1 & 32 \\
\hline Song sparrow & Emergent & 6 & 8 & 33 & 38 & 1 & 5 & 5 & 96 \\
\hline Willow flycatcher & Emergent & 2 & 1 & 1 & 5 & 0 & 0 & 0 & 9 \\
\hline Killdeer & Emergent & 17 & 6 & 1 & 9 & 8 & 0 & 0 & 41 \\
\hline American bittern & Wader & 2 & 0 & 1 & 0 & 0 & 0 & 0 & 3 \\
\hline Common moorhen & Wader & 6 & 0 & 0 & 0 & 0 & 0 & 0 & 6 \\
\hline Great blue heron & Wader & 23 & 0 & 1 & 5 & 18 & 2 & 1 & 50 \\
\hline Great egret & Wader & 1 & 0 & 0 & 0 & 0 & 0 & 0 & 1 \\
\hline Greater yellowlegs & Wader & 0 & 4 & 0 & 0 & 0 & 0 & 0 & 4 \\
\hline Green heron & Wader & 0 & 0 & 1 & 2 & 0 & 0 & 1 & 4 \\
\hline Least bittern & Wader & 0 & 0 & 1 & 0 & 0 & 0 & 0 & 1 \\
\hline Sora & Wader & 1 & 0 & 0 & 0 & 0 & 0 & 0 & 1 \\
\hline Spotted sandpiper & Wader & 3 & 0 & 0 & 0 & 0 & 0 & 0 & 3 \\
\hline Total & & 305 & 125 & 444 & 282 & 231 & 17 & 33 & 1437 \\
\hline
\end{tabular}

wetlands to local HSI specifications is alone insufficient to attract and support particular bird species. This may be a result of imperfect indices [40-43] or confounding factors of landscape, stress, and disturbance. Similarly, our proxy for guild suitability was an unsatisfactory predictor of actual guild abundance. Other researchers $[23,44]$ have provided evidence of general response in bird guilds to changing environmental conditions. It may be that habitat-zone guild suitability is an application for which HSI is not well suited, or it may be that the suitability of local conditions for particular guilds were overwhelmed by landscape factors in these wetlands.
While the predictive power of our study is limited by sample size, the data suggest that landscape-level variables are better predictors of avian abundance than HSI scores. The best predictors of bird abundance in this study were wetland area and buffer width. Larger wetlands support greater numbers of dabbling and wading birds-an effect that might be expected according to the theory of island biogeography [45]. Other authors have found the total wetland area to be a significant predictor of bird species richness and density $[7,17]$. Our regression results indicate that some Ohio mitigation bank wetlands are large enough to support substantial populations of dabbling and wading 
birds, though area appears to be a limiting factor for wetlands smaller than 25 ha. The influence of buffer width has routinely been cited for its role in nutrient dynamics in wetlands [46] and its importance for herptile populations $[47,48]$, though its effects on bird populations are not as well studied. According to Semlitsch and Jensen [49], numerous studies have recommended a terrestrial buffer width of 30 to $60 \mathrm{~m}$ as a means of protecting the wetland from landscape stressors. By this standard, the wetlands in our study are well buffered, with a mean width of over $250 \mathrm{~m}$. Regression models in this study show a potential beneficial effect of buffer width up to $1000 \mathrm{~m}$ for diving and dabbling birds and up to $2000 \mathrm{~m}$ for emergent-dependent birds.

In the wetlands we surveyed, road density and LDI had a weak negative relationship with bird abundance. Findlay and Houlahan [17] indicated that road density is negatively correlated with wetland bird species richness in Ontario. While they find the greatest road density effect at a radius of $500 \mathrm{~m}$, the effect is significant to $2000 \mathrm{~m}$ and corresponds with a $14 \%$ decline in wetland bird species richness for each $2 \mathrm{~m} /$ ha increase in paved road surface. Our regression model for wading birds predicts a $40 \%$ loss of abundance for each $2 \mathrm{~m} / \mathrm{ha}$ increase in road density. The average road density for wetlands in our study, $13 \pm 1 \mathrm{~m} / \mathrm{ha}$, is well above the level at which Findlay and Houlahan [17] noted this effect, suggesting that road density is likely a stress on these wetlands. Anthropogenic stressors are embedded in Mack's [28] LDI for Ohio. Mack [28] found a strong positive correlation of the LDI with the Vegetation Index of Biotic Integrity (VIBI; [50]) for Ohio wetlands, indicating that landscape-level anthropogenic stress is associated with the wetland plant community. For our indicators of the avian community, LDI was a significant predictor for the abundance of only the wading guild.

Our results do not show a strong relationship of bird abundance with the degree of connectedness with adjacent natural areas. The findings of Whited et al. [13] imply that the positive correlation between natural area connectedness and waterbird species richness is strongest at the $2.5 \mathrm{~km}$ interval. At this spatial scale, increases in connectedness were positively associated with the number of waterbird species present in the wetland. In theory, connectedness of natural areas decreases the impact of surrounding land use stresses, such as non-point source pollution or invasive species, by minimizing the length of the perimeter in proportion to the core habitat and reducing the edge effect [13]. Connectedness also increases habitat patch diversity and allows for dispersion among local, native populations within the connected natural area [13]. It may be that the species in our study are not particularly sensitive to connectedness, or the influence of connectedness on bird abundance may be masked by wetland area, buffer width, and landscape stressors.

Given these results on habitat characteristics, landscape features, and bird abundance, we can comment on the capacity of the wetlands in our study to support wetlanddependent bird species. Bird abundance is associated with wetland area, buffer width, and landscape stress to a greater degree than it is associated with local attributes.
Some restored or created wetlands, including some in this study, are large, well-buffered ecosystems that have been placed in relatively low-stress environments. Others, however, provide avian habitat that may be limited by the wetland's configuration or placement within the landscape. Local wetland characteristics that are critical for breeding and survivorship—such as vegetation cover, interspersion, foraging habitat, and nesting sites-are likely to mature and improve as the restored and created wetlands age, but anthropogenic encroachment in the landscape, even at the relatively slow rate of development we note in this study, is likely to become more stressful over time. For this reason, construction of large, well-buffered wetlands in carefully selected locations is a critical consideration in the effort to maximize the functional replacement of avian habitat in restored and created wetlands.

\section{Acknowledgments}

We thank Melissa Kennedy, Jenna Lawson, Alexander Mora, Chelsea Mora, and Jessica Piispanen for their field assistance. This research was funded by the Anderson Scholarship Endowment of Denison University, the Denison University Research Foundation, and the Ohio Biological Survey.

\section{References}

[1] D. Salvesen, Wetlands: Mitigating and Regulating Development Impacts, Urban Land Institute, Washington, DC, USA, 1990.

[2] National Research Council (NRC), Compensating for Wetland Losses under the Clean Water Act, National Academy Press, Washington, DC, USA, 2001.

[3] T. E. Dahl, Status and Trends of Wetlands in the Conterminous United States 1998 to 2004, Department of the Interior, U.S. Fish and Wildlife Service, Washington, DC, USA, 2006.

[4] R. E. Turner, A. M. Redmond, and J. B. Zedler, "Count it by acre or function: mitigation adds up to net loss of wetlands," National Wetlands Newsletter, vol. 23, no. 6, pp. 5-6, 2001.

[5] J. B. Zedler, "Wetlands at your service: reducing impacts of agriculture at the watershed scale," Frontiers in Ecology and the Environment, vol. 1, pp. 65-72, 2003.

[6] J. B. Zedler, "Compensating for wetland losses in the United States," Ibis, vol. 146, supplement 1, pp. 92-100, 2004.

[7] S. E. Fairbairn and J. J. Dinsmore, "Local and landscape-level influences on wetland bird communities of the prairie pothole region of Iowa, USA," Wetlands, vol. 21, no. 1, pp. 41-47, 2001.

[8] D. E. Naugle, K. F. Higgins, S. M. Nusser, and W. C. Johnson, "Scale-dependent habitat use in three species of prairie wetland birds," Landscape Ecology, vol. 14, no. 3, pp. 267-276, 1999.

[9] J. M. Paillisson, S. Reeber, A. Carpentier, and L. Marion, "Plant-water regime management in a wetland: consequences for a floating vegetation-nesting bird, whiskered tern Chlidonias hybridus," Biodiversity and Conservation, vol. 15, no. 11, pp. 3469-3480, 2006.

[10] J. Haitiner, J. B. Zedler, K. E. Boyer, G. D. Williams, and J. C. Callaway, "Influence of physical processes on the design, functioning and evolution of restored tidal wetlands in California (USA)," Wetlands Ecology and Management, vol. 4, no. 2, pp. 73-91, 1997.

[11] U. Özesmi and W. J. Mitsch, "A spatial habitat model for the marsh-breeding red-winged blackbird (Agelaius phoeniceus L.) 
in coastal Lake Erie wetlands," Ecological Modelling, vol. 101, no. 2-3, pp. 139-152, 1997.

[12] T. P. Milsom, S. D. Langton, W. K. Parkin et al., "Habitat models of bird species' distribution: an aid to the management of coastal grazing marshes," Journal of Applied Ecology, vol. 37, no. 5, pp. 706-727, 2000.

[13] D. Whited, S. Galatowitsch, J. R. Tester, K. Schik, R. Lehtinen, and J. Husveth, "The importance of local and regional factors in predicting effective conservation planning strategies for wetland bird communities in agricultural and urban landscapes," Landscape and Urban Planning, vol. 49, no. 1-2, pp. 49-65, 2000.

[14] D. E. Naugle, R. R. Johnson, M. E. Estey, and K. F. Higgins, "A landscape approach to conserving wetland bird habitat in the prairie pothole region of Eastern South Dakota," Wetlands, vol. 21, no. 1, pp. 1-17, 2001.

[15] W. G. Shriver, T. P. Hodgman, J. P. Gibbs, and P. D. Vickery, "Landscape context influences salt marsh bird diversity and area requirements in New England," Biological Conservation, vol. 119, no. 4, pp. 545-553, 2004.

[16] D. M. Mensing, S. M. Galatowitsch, and J. R. Tester, "Anthropogenic effects on the biodiversity of riparian wetlands of a northern temperate landscape," Journal of Environmental Management, vol. 53, no. 4, pp. 349-377, 1998.

[17] C. S. Scott Findlay and J. Houlahan, "Anthropogenic correlates of species richness in southeastern Ontario wetlands," Conservation Biology, vol. 11, no. 4, pp. 1000-1009, 1997.

[18] M. A. Cunningham and D. H. Johnson, "Proximate and landscape factors influence grassland bird distributions," Ecological Applications, vol. 16, no. 3, pp. 1062-1075, 2006.

[19] J. P. Kelly, D. Stralberg, K. Etienne, and M. McCaustland, "Landscape influence on the quality of heron and egret colony sites," Wetlands, vol. 28, no. 2, pp. 257-275, 2008.

[20] R. B. Root, "The niche exploitation pattern of the blue-gray gnatcatcher," Ecological Monographs, vol. 37, pp. 317-350, 1967.

[21] D. Simberloff and T. Dayan, "The guild concept and the structure of ecological communities," Annual Review of Ecology and Systematics, vol. 22, no. 1, pp. 115-143, 1991.

[22] W. V. DeLuca, C. E. Studds, L. L. Rockwood, and P. P. Marra, "Influence of land use on the integrity of marsh bird communities of Chesapeake Bay, USA," Wetlands, vol. 24, no. 4, pp. 837-847, 2004.

[23] M. J. Croonquist and R. P. Brooks, "Use of avian and mammalian guilds as indicators of cumulative impacts in riparian-wetland areas," Environmental Management, vol. 15, no. 5, pp. 701-714, 1991.

[24] J. Hanowski, N. Danz, R. Howe, G. Niemi, and R. Regal, "Consideration of geography and wetland geomorphic type in the development of Great Lakes coastal wetland bird indicators," EcoHealth, vol. 4, no. 2, pp. 194-205, 2007.

[25] S. Goetz, D. Steinberg, R. Dubayah, and B. Blair, "Laser remote sensing of canopy habitat heterogeneity as a predictor of bird species richness in an eastern temperate forest, USA," Remote Sensing of Environment, vol. 108, no. 3, pp. 254-263, 2007.

[26] B. L. Swift, J. S. Larson, and R. M. Degraaf, "Relationship of breeding bird density and diversity to habitat variables in forested wetlands," The Wilson Bulletin, vol. 96, no. 1, pp. 4859, 1984.

[27] J. Verner, "The guild concept applied to management of bird populations," Environmental Management, vol. 8, no. 1, pp. 1$14,1984$.
[28] J. J. Mack, "Landscape as a predictor of wetland condition: an evaluation of the landscape development index (LDI) with a large reference wetland dataset from Ohio," Environmental Monitoring and Assessment, vol. 120, no. 1-3, pp. 221-241, 2006.

[29] A. W. Allen, Habitat Suitability Index Models: American Coot, Biological Report 82(10.115), U.S. Fish and Wildlife Service, 1985.

[30] A. W. Allen, Habitat Suitability Index Models: Lesser Scaup (Breeding), Biological Report 82(10.117), U.S. Fish and Wildlife Service, 1986.

[31] P. J. Sousa and A. H. Farmer, Habitat Suitability Index Models: Wood Duck, U.S. Fish and Wildlife Service, 1983, FWS/OBS$82 / 10.43$

[32] P. J. Sousa, Habitat Suitability Index Models: Blue-Winged Teal (Breeding), Biological Report 82(10.114), U.S. Fish and Wildlife Service, 1985.

[33] B. R. Chapman and R. J. Howard, Habitat Suitability Index Models: Great Egret, U.S. Fish and Wildlife Service, 1984, FWS/OBS-82/10.78.

[34] H. L. Short and R. J. Cooper, Habitat Suitability Index Models: Great Blue Heron, Biological Report 82(10.99), U.S. Fish and Wildlife Service, Washington, DC, USA, 1985.

[35] K. J. Gutzwiller and S. H. Anderson, Habitat Suitability Index Models: Marsh Wren, Biological Report 82(10.139), U.S. Fish and Wildlife Service, Washington, DC, USA, 1987.

[36] H. L. Short, Habitat Suitability Index Models: Red-Winged Blackbird, Biological Report 82(10.95), U.S. Fish and Wildlife Service, Washington, DC, USA, 1985.

[37] M. T. Brown and M. B. Vivas, "Landscape development intensity index," Environmental Monitoring and Assessment, vol. 101, no. 1-3, pp. 289-309, 2005.

[38] H. Poysa and P. Nummi, "Comparing two methods of data collection in waterfowl habitat use studies," Bird Study, vol. 39, no. 2, pp. 124-131, 1992.

[39] P. R. Ehrlich, D. S. Dobkin, and D. Wheye, The Birder's Handbook: A Field Guide to the Natural History of North American Birds, Simon and Schuster, New York, NY, USA, 1988.

[40] R. P. Brooks, "Improving habitat suitability index models," Wildlife Society Bulletin, vol. 25, no. 1, pp. 163-167, 1997.

[41] G. R. Roloff and B. J. Kernohan, "Evaluating reliability of habitat suitability index models," Wildlife Society Bulletin, vol. 27, no. 4, pp. 973-985, 1997.

[42] T. S. Beutel, R. J. S. Beeton, and G. S. Baxter, "Building better wildlife-habitat models," Ecography, vol. 22, no. 2, pp. 219223, 1999.

[43] G. E. M. van der Lee, D. T. van der Molen, H. F. P. van den Boogaard, and $\mathrm{H}$. van der Klis, "Uncertainty analysis of a spatial habitat suitability model and implications for ecological management of water bodies," Landscape Ecology, vol. 21, no. 7, pp. 1019-1032, 2006.

[44] T. J. O’Connell, L. E. Jackson, and R. P. Brooks, "Bird guilds as indicators of ecological condition in the central Appalachians," Ecological Applications, vol. 10, no. 6, pp. 1706-1721, 2000.

[45] R. H. MacArthur and E. O. Wilson, The Theory of Island Biogeography, Princeton University Press, Princeton, NJ, USA, 1967.

[46] J. Uusi-Kämppä, B. Braskerud, H. Jansson, N. Syversen, and R. Uusitalo, "Buffer zones and constructed wetlands as filters for agricultural phosphorus," Journal of Environmental Quality, vol. 29, no. 1, pp. 151-158, 2000.

[47] V. J. Burke and J. W. Gibbons, "Terrestrial buffer zones and wetland conservation: a case study of freshwater turtles in 
a Carolina Bay," Conservation Biology, vol. 9, no. 6, pp. 13651369, 1995.

[48] R. D. Semlitsch and J. R. Bodie, "Biological criteria for buffer zones around wetlands and riparian habitats for amphibians and reptiles," Conservation Biology, vol. 17, no. 5, pp. 1219$1228,2003$.

[49] R. D. Semlitsch and J. B. Jensen, "Core habitat, not buffer zone," National Wetlands Newsletter, vol. 23, no. 4, pp. 5-6, 2001.

[50] J. J. Mack, "Vegetation indices of biotic integrity (VIBI) for wetlands: ecoregional, hydrogeomorphic, and plant community comparison with preliminary wetland aquatic lifeuse designations," Ohio Environmental Protection Agency, Division of Surface Water, Wetland Ecology Group, Columbus, Ohio, 2001. 

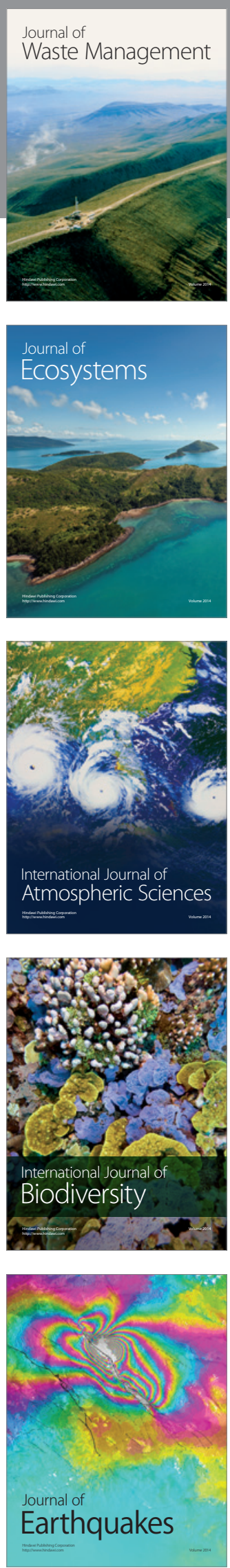
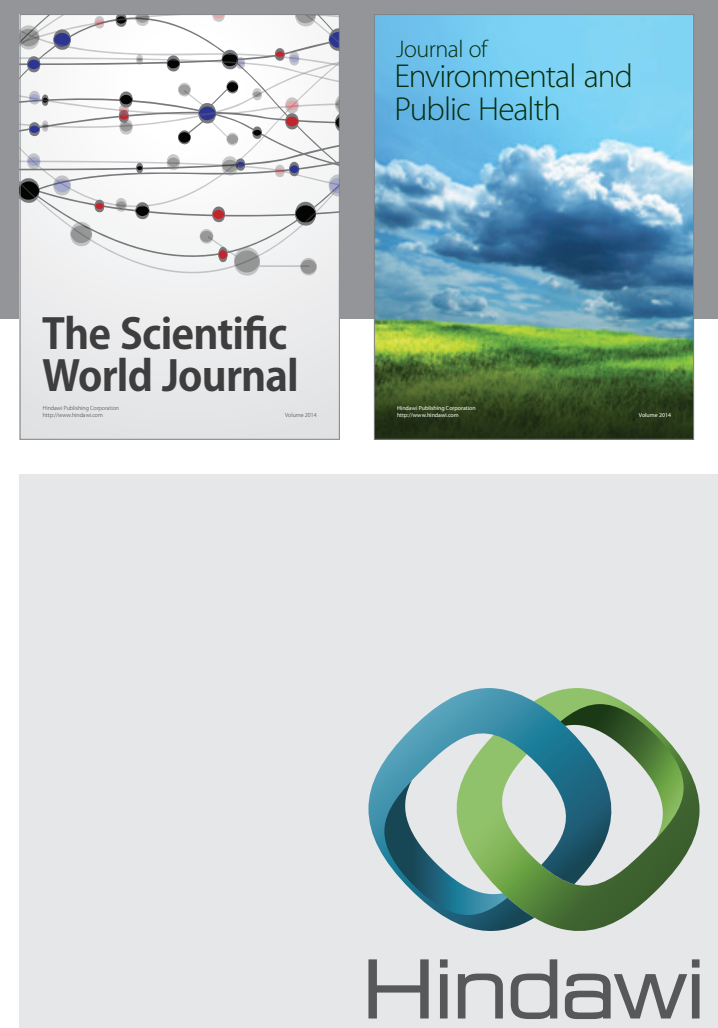

Submit your manuscripts at

http://www.hindawi.com
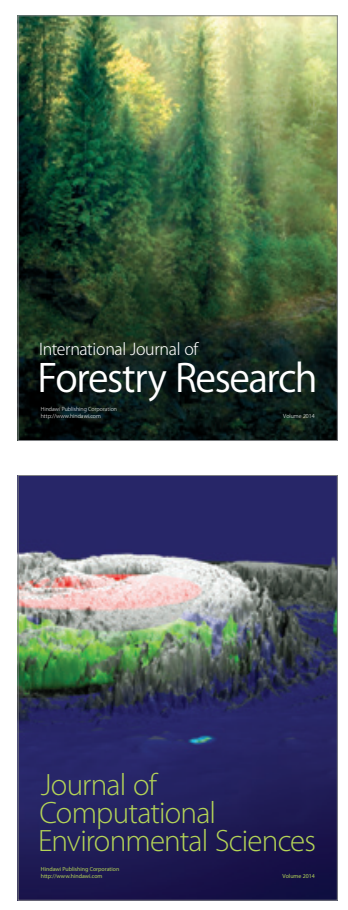
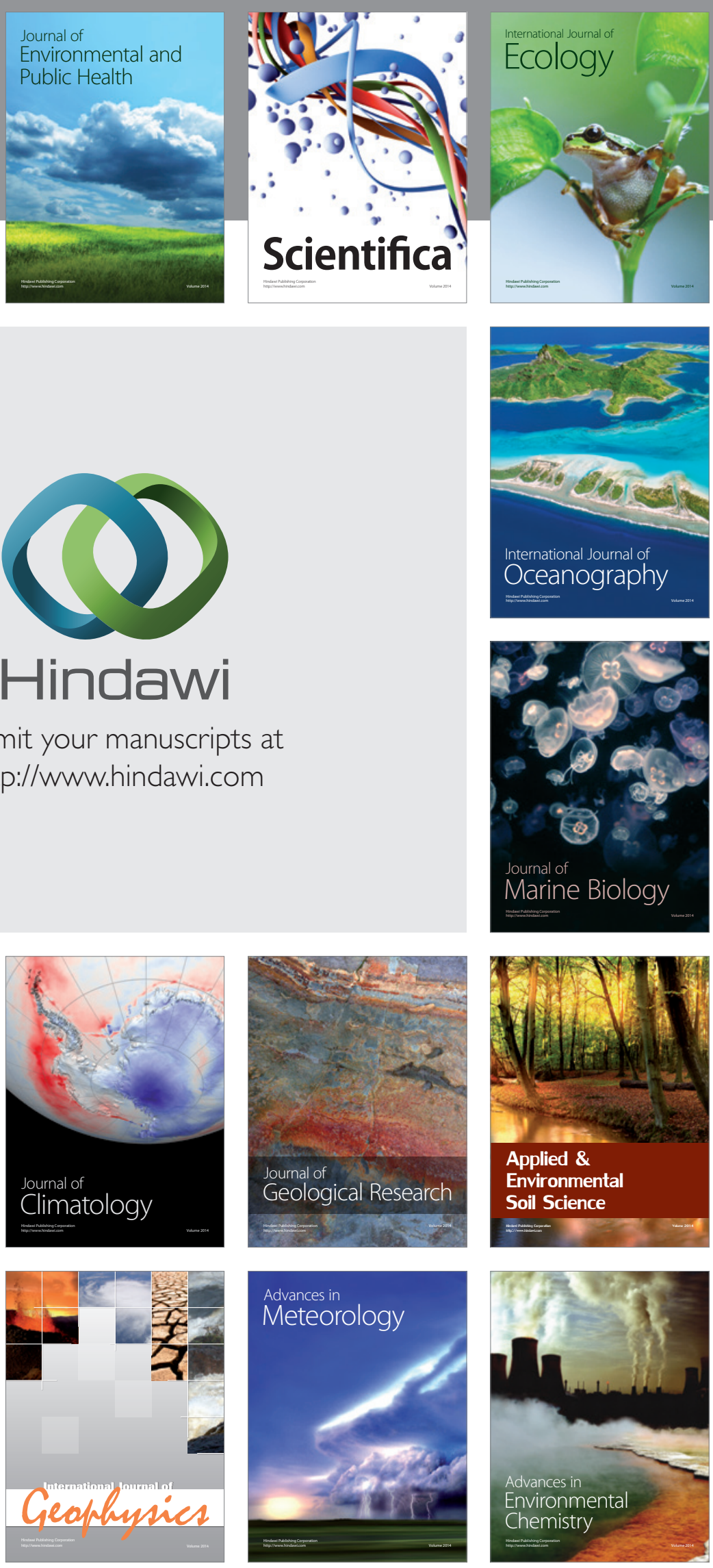